\title{
Biological and Chemical Techniques for Integrated Control of the Spiny Bollworm, Earias insulana (Boisd.) (Lep., Noctuidae)
}

\author{
Saad', A. S. A., E. H. M. Tayeb1, Mahasen M. Ibrahim² and \\ Noha A. M. El-Habal ${ }^{2}$ \\ 1- Plant Protection Dept., Fac. Agric. (Saba Basha), Alex. Univ., P.O Box 21531-Bolkly, \\ Alex., Egypt \\ 2- Plants Protection Institute, Agriculture Res. Station, El-Sabahia, Alexandria
}

\begin{abstract}
ABST RACT: Field experiments were carried out during the cotton seasons of 2103 and 2014 in a private farm at Abo-Homos District, El-Behaira Governorate to evaluate the efficiency of the release of the parasitoid Trichogramma evanescens alone or in different combinations with different insecticides on the mean numbers of the cotton spiny bollworm (Earias insulana) (Boisd) larvae, in addition to their effect on seed cotton yield and economic loss. The obtained results indicated that the treatmental combination of the parasitoid T. evanescens+ Radiant ${ }^{\Theta}$ gave the lowest infestation level (1.22 larvae/75 bolls) as compared with the untreated check (17.61 larvae/75 bolls) during the cotton season of 2013. Meanwhile, T. evanescens+ Pleo ${ }^{\circledR}$ gave the highest seed cotton yield $(8.98 \mathrm{ken} / \mathrm{fed}$.), versus the lower one of the untreated check (4.31 ken / fed.). Also, the treatmental combination of $T$. evanescens+ Fertilizer (Novatic slop $\left.48^{\circledR}\right)+$ different insecticides $\left(\right.$ Oshin $^{\circledR}$, Nomol ${ }^{\circledR}$ and Pestban ${ }^{\circledR}$ ) gave the lowest loss of cotton bolls $(10.00 \%)$ and more or less higher cotton yield and loss of bolls in comparison to the untreated check (4.31ken / fed. and 49.20\%, respectively) during the same cotton season of 2013.
\end{abstract}

During the cotton season of 2014, the performed combination of Trichogramma evanescens+ Fertilizer + consequential insecticides (Oshin ${ }^{\circledR}$, Nomolt ${ }^{\circledR}$ and Radiant ${ }^{\circledR}$ ) gave the lowest larval infestation ( 0.50 larvae/75 bolls ) as compared with the untreated check (17.33 larvae/ 75 bolls). By the end of 2014 cotton season, the treatment of T. evanescens + (Pleo ${ }^{\circledR}$, Challenger ${ }^{\circledR}$ and $\mathrm{Pleo}^{\circledR}$ ) gave the highest seed cotton yield of $9.43 \mathrm{ken} / \mathrm{fed}$. and the lowest loss of cotton bolls $(6.50 \%)$ in comparison to the untreated check (4.14 ken and $48.50 \%$, respectively ). It could be concluded that all the performed treatments of the release of $T$. evanescens in combinations with the tested insecticides showed the best integration for bollworms control and recorded higher yield and lower loss value than those of the untreated check.

Key words: Spiny bollworm, Integrated Control, Trichogramma evanescens, Insecticides, Seed Cotton yield and loss.

\section{INTRODUCTION}

In Egypt, the spiny and pink bollworms are the key pests of cotton (Amin and Gergis, 2006). The Egyptian bollworm Earias insulana (Boisd) (Lepidoptera: Noctuidae) is considered to be the most serious and destructive insect-pest of cotton bolls (Hussein et al., 2002). This injurious insect-pest is most damaging on irrigated cotton in drier countries, particularly in Egypt, Sudan, Israel, Pakistan and North India. Its name is being derived from the characteristic bristles or spines which are found on larvae. The initial damage to the cotton crop by the spiny bollworm occurs in early stages of plant growth. The larva enters near the terminal bud and then burrows down inside the main stem causing the death of the main stem growing point. This is not generally serious for the side branches which grow in compensation and producing a bushy plant with a large yield potential, despite fruiting in this case may be delayed. On older cotton this pest feeds in buds, flowers and bolls. It tends to be an internal feeder and is more commonly found in bolls (Reed, 1977). Alternative host plants (okra, maize [in Egypt] and other Malvales) play an important role in the carryover of Earias spp to cotton (Saini and Singh, 2002; Bhatti et al., 2007; Mirmoayedi and Maniee, 2009). 
In Egypt, it is noticed that cotton cultivated area decreases annually and in the last five years, farmers do not prefer to cultivate cotton because of the high costs of both cotton pest control and cotton hand picking, accompanied with the low price of seed cotton yield that does not cover the costs of cotton production (Aziz, 2011). Moreover, the government has decided to stop cash subsidies to farmers and spinners (USDA Foreign Agricultural Service, 2015) Damage to cotton crop by insect pests throughout the world results in a significant yield loss each year (Al-Ameer et al., 2010) and therefore many authors investigated the effect of the chemical techniques by evaluating certain individual insecticides as well as their combined action on the spiny bollworm (El-Basyouni, 2003; Younis et al., 2007; Mirmoayedi et al., 2010; Elgohary, 2014). The control of cotton insect pests remains an unabated challenge (Johnstone, 2006).

The egg parasitoids, Trichogramma spp are common biological control agents that have been successfully used in biological control programs for a variety of lepidopteran pests. Trichogramma species are being used widely in IPM programs on many important insect-pests including the spiny bollworm Earias insulana (Boisd.) (Li, 1994).

The combined effect of the chemical and biological measures was also investigated (Mirmoayedi and Maniee, 2009; El-Bassiuony, 2012; Saad et al., 2015). It would be desirable if any potential insecticide could be used in good combinations with some beneficial biological control agents under the concept of integrated pest management program. With a proper planning and timing of application of insecticides together with the release of known biological control agents, it might result in the best means of insect-pests integrated control. This also would give a great deal of contributions to the farmers in terms of reducing the cost of crops production whilst in the same time increasing the profit margins as well as reducing the toxic remains (pollutants) in the plants or the environment.

The present study was conducted to evaluate certain biological and chemical treatmental techniques that can be used together for integrated control of the spiny bollworm, Earias insulana (Boisd.) (Lep.: Noctuidae) by releasing the parasitoid Trichogramma evanescens in combinations with different chemical treatments (insecticides) to measure their effect on the occurrence or incidence of the spiny bollworm (Earias insulana); yield and loss of cotton due to insect infestation.

\section{MATERIALS AND METHODS Field Experiments}

Field experiments were carried out in a private farm at Abo-Homos District, El-Behaira Governorate, during two successive growing cotton seasons of 2103 and 2014. The experimental area of half feddan was cultivated with cotton variety "Giza86" on May, the $27^{\text {th }}$ and the $15^{\text {th }}$ during both the following seasons, respectively. The effect of different inspected treatments (programs or combinations) against the spiny bollworm was studied to select the best program that can be recommended for its integrated control management. The 
area was arranged in randomized complete block design with three replicates (7X6 m) for each treatment $(7 \mathrm{X} 18 \mathrm{~m})$.

\section{The release of parasitoid Trichgramma evanescens}

The release of parasitoid Trichgramma evanescens was started 60 days after sowing.The parasitoid was released as pupae within the parasitized Sitotroga cerealella eggs at a rate of $23100-26400$ parasitoids/feddan. The release of the parasitoid was applied in the field using a device to protect them from the predators and unfavorable weather conditions. To decrease the labor cost, the device which consists of thick paper card $(8 \times 12 \mathrm{~cm})$ was modified; as it was folded to make a closed container $(8 \times 6 \mathrm{~cm})$. Three cards of the Angoumois grain moth Sitotroga cerealella eggs $(1 \times 1 \mathrm{~cm})$ containing parasitoid pupae (about 350-400 pupae/card) of three different stages of development (1, 2 and 3 days before adults emergence) were glued in this container with a total number of 1050-1200 parasitoids / 3 cards.

The cards were hanged manually before the sunset on the lower plant canopy at a distance of about $50 \mathrm{~cm}$ above the ground. Each feddan required about 22 cards; though the rate of releasing comprised 22 paper cards/feddan/ release (2cards/2kerat). In the first season, five releases were carried out while in the second season of 2014 , six releases were done. The distance between the release points was $10 \mathrm{~m}$ and started $5 \mathrm{~m}$ apart from the edges of the field. When the infestation level arrived 3\%, the tested insecticides (that have been selected for the spiny bollworm) were applied to decrease the infestation of the spiny cotton bollworm $E$. insulana.

\section{Tested compounds}

All agrochemicals used in the course of the present study were supplied by Shora Chemical, Egypt and they were:

\section{A- Pesticides:}

1. Flutolanil (Moncut ${ }^{\circledR} 25 \%$ WP) is a fungicide which has been used for seeds treatment before sowing at the rate of $3 \mathrm{~g} / \mathrm{kg}$ seeds.

2. Dinotefuran (Oshin ${ }^{\circledR} 20 \%$ SG) is a systemic insecticide and it was used for controlling cotton sucking insects; sprayed early during the vegetative growth (250 g/feddan).

3. Teflubenzuron (Nomolt15\% SC) (an insect growth regulator, I.G.R.) was used for controlling the cotton leaf worm; sprayed during the vegetative growth (100 ml/feddan).

4. Diflubenzuron (Demeron ${ }^{\circledR} 10 \%$ E.C.) an insect growth regulator (I.G.R.) that has been used for controlling the cotton leafworm cotton during the vegetative growth (200 $\mathrm{ml} /$ feddan).

The following insecticides were used for controlling the spiny bollworm $E$. insulana:

5. Profenofos (Teliton ${ }^{\circledR} 72 \%$ EC) (an organophosphorous insecticde) (750 $\mathrm{ml} /$ feddan).

6. Pyridalyl (Pleo ${ }^{\circledR} 50 \%$ EC) $(100 \mathrm{ml} /$ feddan).

7. Spinetoram (Radiant ${ }^{\circledR} 12 \%$ SC) (35 ml/feddan).

8. Chlorpyrifos (Pestban ${ }^{\circledR} 48 \%$ EC)(an organophosphorous insecticide)(1 liter/feddan).

9. Chlorfenapyr (Challenger ${ }^{\circledR} 36 \%$ EC) (120 ml/feddan). 
B- Fertilizers:

1. Novatic slop $48^{\circledR}$ was added with irrigation water (17 kg/feddan) before flowering.

\section{C- Herbicides:}

1. Pendimethalin (Stomp Exstra ${ }^{\circledR} 45.5 \%$ CS) (1.5 liter/feddan) is an herbicide and it was applied for all the performed treatments to control weeds after sowing (pre-emegence).

Tested compounds were sprayed using a knapsack sprayer (CP3) at rate of 100 liters/feddan. Mean numbers of spiny bollworm larvae/75 bolls (25 bolls /replicate) were estimated immediately before the first spray and then every week throughout the period of experiment. All the different performed treatments (combinations) are summarized in Table (1).

\section{Determination of cotton yield}

In each treatment, ripened open bolls from forty cotton plants were collected to determine the cotton yield / plant and from which, the total yield /feddan was relatively calculated as follows:

$$
\text { Yield }=\frac{\text { plant yield }(\mathrm{g}) \times \text { No. of plants per fed }(45000)}{1000}=\frac{\mathrm{kg} / \mathrm{fed} .}{157.5}=\mathrm{Ken} . / \mathrm{fed} .
$$

where a kentar (ken.) of seed cotton $=157.5 \mathrm{~kg}$ and fed. $=$ feddan $=4200 \mathrm{~m}^{2}$

\section{Cotton yield loss}

The potential yield losses at the end of each cotton season and the economic loss percentages were determined according to Hosny et al. (1967).

\section{Statistical analysis}

All data were subjected to one-way analysis of variance (ANOVA) followed by Duncan multiple range test (Duncan, 1955 ) to determine the significant differences among treatments mean values at 0.05 probability level.

\section{RESULTS AND DISCUSSION}

The efficiency of releasing the beneficial parasitoid Trichogramma evanescens alone or combined with the application of different insecticides on the mean numbers of the cotton spiny bollworm ( $E$. insulana) larvae/75 bolls, yield and cotton loss during two consequent growing cotton seasons of 2013 and 2014 is investigated.

\section{Season of 2013}

Data in Table (2) indicated that all run treatments induced significant effect on the population of the spiny bollworm larvae expressed as means numbers of larvae / 75 bolls and compared with the untreated check (control). It is obvious that the lowest infestation rate by the spiny bollworm was recorded using the treatment of $T$. evanescens + Radiant $^{\circledR}$ (T2) with 1.22 larvae/75 bolls, followed by the treatment of T.evanescens+ Ferttilizer $+\left(\right.$ Oshin ${ }^{\circledR}$, Pestban $\left.^{\circledR}\right)$ (T5) with 1.61 larvae/75 bolls as compared with the untreated check which recorded a highest mean value of 17.61 larvae/ 75 bolls. 
Table (1): The suggested different treatments (combinations) during both the cotton growing seasons of 2013 and 2014

\begin{tabular}{|c|c|c|}
\hline \multirow{2}{*}{ Treatments } & \multicolumn{2}{|c|}{ Cotton Season } \\
\hline & 2013* & 2104 \\
\hline T1 & T. evanescens $+3^{\#}$ sprays of Pleo ${ }^{\circledR}$ & T. evanescens +4 sprays of Pleo ** \\
\hline T2 & T. evanescens +3 sprays of Radiant ${ }^{\circledR}$ & T. evanescens +4 sprays of Radiant ${ }^{\circledR}$ \\
\hline T3 & T. evanescens +3 sprays of Pestban ${ }^{\circledR}$ & T. evanescens +4 sprays of Pestban ${ }^{\circledR}$ \\
\hline $\mathrm{T4}^{\star *}$ & T. evanescens $+\left(1\right.$ Oshin $^{\circledR}, 1$ Nomolt $^{\circledR}, 3$ Pestban $\left.^{\circledR}\right)($ in sequence $)$ & T. evanescens $+\left(1 \mathrm{Pleo}^{\circledR}, 1\right.$ Challenger $\left.^{\circledR}, 2 \mathrm{Pleo}^{\circledR}\right)$ \\
\hline T5 & T. vanescens. + Fertilizer $+\left(1\right.$ Oshin $^{\circledR}, 3$ Pestban $\left.{ }^{\circledR}\right)$ & T. evanescens $+\left(\right.$ 1Oshin $\left.^{\circledR}, 1 \mathrm{Nomolt}^{\circledR}, 4 \mathrm{Pleo}^{\circledR}\right)$ \\
\hline T6 & T. evanescens + Fertilizer $+\left(1\right.$ Oshin $^{\circledR}, 1$ Nomolt $^{\circledR}, 3$ Pestban $\left.{ }^{\circledR}\right)$ & T. evanescens $+\left(\right.$ 1Oshin $^{\circledR}$, Nomolt $^{\circledR}, 4$ Radiant $\left.^{\circledR}\right)$ \\
\hline T7 & R. A.P $^{* * *}\left(2\right.$ Demeron $^{\circledR}, 2$ Pestban $^{\circledR}$, 1Teliton $\left.^{\circledR}\right)$ & T. evanescens $+\left(\right.$ 1Oshin ${ }^{\circledR}, 1$ Nomolt $^{\circledR}, 4$ Pestban $\left.^{\circledR}\right)$ \\
\hline T8 & 1Oshin $^{\circledR}, 1$ Nomolt $^{\circledR}, 3 \mathrm{Pleo}^{\circledR}$ & $F^{* * *}+T$. evanescens $+\left(1\right.$ oshin $^{\circledR}, 1$ Nomolt $^{\Theta}, 4$ Pestban $\left.^{\circledR}\right)$ \\
\hline T9 & 1Oshin ${ }^{\circledR}, 1$ Nomolt $^{\circledR}, 3$ Radiant $^{\circledR}$ & Trichogramma evanescens (alone) \\
\hline T10 & Untreated check (control) & F. + T. evanescens +1 Oshin $^{\circledR}, 1$ Nomolt $\left.^{\circledR}, 4 \mathrm{Pleo}^{\circledR}\right)$ \\
\hline T11 & 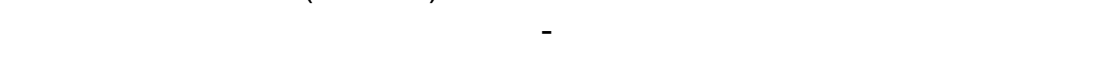 & F. + T. evanescens $+\left(1\right.$ Oshin $^{\circledR}, 1$ Nomolt $^{\circledR}, 4$ Radiant $^{\circledR}$ \\
\hline T12 & - & R.A.P. ${ }^{* * *} \cdot\left(2\right.$ Demeron $^{\circledR}, 2$ Pestban ${ }^{\circledR}, 2$ Teliton $\left.^{\circledR}\right)$ \\
\hline T13 & - & $\left(1\right.$ Oshin $^{\circledR}, 1$ Nomolt $^{\circledR}, 4$ Pestban $\left.^{\circledR}\right)$ \\
\hline T14 & - & $\left(1\right.$ Oshin $^{\circledR}, 1$ Nomolt $^{\circledR}$, 4Radiant $\left.^{\circledR}\right)$ \\
\hline T15 & - & $\left(1\right.$ Oshin $^{\circledR}, 1$ Nomolt $\left.^{\circledR}, 4 \mathrm{Pleo}^{\circledR}\right)$ \\
\hline T16 & 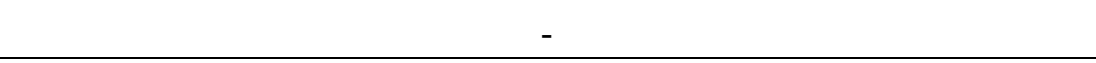 & Untreated check (control) \\
\hline${ }^{\star \star}{ }^{\star \star *} \mathrm{O}$ & (Novatic slop 48 & 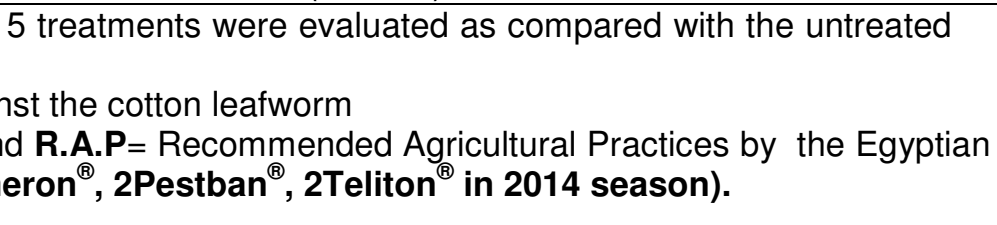 \\
\hline
\end{tabular}


Table (2): Effect of Trichogramma evanescens release and application of different insecticides on the mean numbers of the spiny bollworm larvae/75 bolls during the season of 2013

\begin{tabular}{|c|c|c|c|c|c|c|c|c|c|c|c|}
\hline \multirow[b]{3}{*}{ Treatment } & \multirow[b]{3}{*}{ M.N.B.S\# } & \multicolumn{9}{|c|}{ Mean No. of the spiny bollworm larvae } & \multirow[b]{3}{*}{$\begin{array}{c}\text { General } \\
\text { Mean }\end{array}$} \\
\hline & & \multicolumn{3}{|c|}{$1^{\text {st }}$ Spray } & \multicolumn{3}{|c|}{$2^{\text {nd }}$ Spray } & \multicolumn{3}{|c|}{$3^{\text {rd }}$ Spray } & \\
\hline & & $\begin{array}{c}1^{\text {st }} \\
\left(31 / 8^{\star}\right)^{\star \star \star}\end{array}$ & $\begin{array}{l}2^{\text {nd }} \\
(7 / 9)\end{array}$ & $\begin{array}{c}\text { Mean No. } \\
\text { of } \\
\begin{array}{c}\text { larvae/75 } \\
\text { bolls }\end{array}\end{array}$ & $\begin{array}{c}3^{\text {rd }} \\
(15 / 9)\end{array}$ & $\begin{array}{c}4^{\text {th }} \\
(23 / 9)\end{array}$ & $\begin{array}{c}\text { Mean No. } \\
\text { of } \\
\text { larvae/75 } \\
\text { bolls }\end{array}$ & $\begin{array}{c}5^{\text {th }} \\
(3 / 10)\end{array}$ & $\begin{array}{c}6^{\text {th }} \\
(10 / 10)\end{array}$ & $\begin{array}{c}\text { Mean No. } \\
\text { of } \\
\text { larvae/75 } \\
\text { bolls }\end{array}$ & \\
\hline T1 & 0.00 & $0.00^{\mathrm{d}^{* *}}$ & $3.66^{\mathrm{C}}$ & $1.83^{\mathrm{e}}$ & $3.00^{\text {cd }}$ & $3.33^{\mathrm{cd}}$ & $3.16^{\mathrm{C}}$ & $2 \cdot 00^{b}$ & $1.00^{\mathrm{b}}$ & $1.50^{\mathrm{bc}}$ & $2.16^{\mathrm{de}}$ \\
\hline T2 & 2.67 & $0.00^{d}$ & $2.33^{\mathrm{C}}$ & $1.16^{\mathrm{e}}$ & $2 \cdot 00^{d}$ & $1.66^{\mathrm{e}}$ & $1.83^{\mathrm{de}}$ & $1.00^{\mathrm{b}}$ & $0.33^{b}$ & $0.66^{\mathrm{bc}}$ & $1.22^{\mathrm{e}}$ \\
\hline T3 & 3.67 & $1.33^{\mathrm{cd}}$ & $2.66^{\mathrm{C}}$ & $2.00^{\mathrm{de}}$ & $3.66^{\mathrm{bcd}}$ & $5.00^{b}$ & $4.33^{\mathrm{e}}$ & $2.33^{b}$ & $1.00^{\mathrm{b}}$ & $1.66^{\mathrm{c}}$ & $2.66^{\mathrm{e}}$ \\
\hline T4 & 3.00 & $1.00^{\mathrm{cd}}$ & $3.33^{c}$ & $2.16^{\mathrm{de}}$ & $4.66^{b c}$ & $3.33^{\mathrm{cd}}$ & $4.00^{d}$ & $1.00^{\mathrm{b}}$ & $1.00^{\mathrm{b}}$ & $1.00 \mathrm{bc}$ & $2.39^{\mathrm{de}}$ \\
\hline T5 & 3.67 & $2.33^{\mathrm{cd}}$ & $1.66^{\mathrm{c}}$ & $2.00^{\mathrm{de}}$ & $2.66^{\mathrm{cd}}$ & $1.66^{\mathrm{e}}$ & $2.16^{\mathrm{e}}$ & $1.00^{\mathrm{b}}$ & $0.33^{b}$ & $0.66^{b c}$ & $1.61^{\mathrm{e}}$ \\
\hline T6 & 5.00 & $3.66^{b c}$ & $4.33^{c}$ & $4.00^{\mathrm{cd}}$ & $4.33^{\mathrm{bcd}}$ & $3.00^{d}$ & $3.66^{d}$ & $2.33^{b}$ & $0.66^{b}$ & $1.50^{c}$ & $3.05^{d}$ \\
\hline T7 & 7.67 & $6.00^{c}$ & $4.66^{c}$ & $5.33^{c}$ & $3.66^{\mathrm{bcd}}$ & $3.33^{\mathrm{cd}}$ & $3.5 d^{e}$ & $400^{b}$ & $1.00^{b}$ & $2.50^{b}$ & $3.78^{c}$ \\
\hline T8 & 10.33 & $6.33^{b}$ & $7.66^{b}$ & $7.00^{\mathrm{b}}$ & $5.66^{b}$ & $4.66^{\mathrm{bc}}$ & $5.16^{b}$ & $3.66^{b}$ & $1.66^{b}$ & $2.66^{b}$ & $4.94^{b}$ \\
\hline T9 & 3.67 & $3.00^{\mathrm{cd}}$ & $2.33^{\mathrm{C}}$ & $2.66^{\mathrm{de}}$ & $3.33^{\mathrm{bcd}}$ & $3.33^{\mathrm{cd}}$ & $3.33^{\text {de }}$ & $2.33^{b}$ & $1.00^{b}$ & $1.66 b^{c}$ & $2.55^{\mathrm{de}}$ \\
\hline $\begin{array}{c}\text { Untreated } \\
\text { Check }\end{array}$ & 15.00 & $18.33^{a}$ & $15.66^{a}$ & $17.00^{a}$ & $17.33^{a}$ & $19 \cdot 00^{a}$ & $18.16^{a}$ & $16.33^{a}$ & $19^{a}$ & $17.66^{\mathrm{a}}$ & $17.61^{a}$ \\
\hline
\end{tabular}

\# Mean numbers of larvae before Spray

*Inspection date (day/Month)

** Means followed with the same letter(s) (in a column) are not significantly different at 0.05 level of probability.

${ }^{* * *} 1^{\text {st }}$ inspection was done 7 days post- application and $2^{\text {nd }}$ one was done 14 days post-application. 
It was noticed that there were no significant differences between the treatments of $T$. evanescens + one insecticide) (T1, T2, T3) and T9 (three sequential insecticides). Therefore, to reduce the environmental pollution, it is recommended to release the parasitoid $T$. evanescens combined with the cheapest insecticide of each of the three effective ones (Pleo ${ }^{\circledR}$, Radiant ${ }^{\circledR}$ or Pestban ${ }^{\circledR}$ ) to obtain the same efficiency for controlling the spiny bollworm.

These above presented results are in agreement with those of Gergis et al. (2001) who found that the program of releasing the parasitoid Trichogramma evanescens with one insecticide spray achieved the highest rate of reduction of the spiny and pink bollworms. Moreover, El-Bassiuony (2012) proved that the release of the parasitoid Trichogramma evanescens with one spray of spinotram when the infestation level increased up to $3 \%$ was the most effective against bollworms.

It could be also concluded that all our performed and run treatments were effective in reducing the larvae of the spiny bollworm as compared with the highest mean number of 17.61 larvae/75 bolls (untreated check).

The results illustrated in Table (3) show that the highest attained yield (8.98ken./fed.) has been recorded for the treatment of $T$. evanescens + Pleo ${ }^{\circledR}$ (T1); that yield was as twice as that of the control, followed by the less higher yield resulted from T2 (8.23 ken./fed.) (T. evanescens + Radiant $^{\circledR}$ ). All the performed combinations achieved more or less high cotton yield (5.037.97ken./fed.) as compared with that low yield of control (4.31ken. /fed.).

The assigned loss of cotton bolls of control due to the infestation of spiny bollworm compared with the recorded loss of the parasitoid+ each of the tested insecticides in the different suggested treatments is represented in Table (4).Herein, T6 and T1 showed merely similar lower percentage of cotton loss (10.00 and 10.30). Vice versa, the control treatment recorded the highest percentage of loss that has been calculated by $49.20 \%$; that loss was as five times as that of T1 and T2. This result indicates the importance of using the profitable and efficient biological and chemical techniques combined together for the integrated control of the spiny bollworm $E$. insulana.

Again, all the performed treatments of the parasitoid combined with the tested insecticides or using certain insecticides alone were effective in reducing cotton loss during the season of 2013.

\section{Season of 2014}

The detected infestation level with the spiny bollworm during the cotton growing season of 2014 was expressed as the mean number of larvae/75 bolls. Data presented in Table (5) reveal that all run treatments induced significant effects on the population of the spiny bollworm larvae compared with the untreated check. The treatment of $T$. evanescens + Ferttilizer $+\left(\right.$ Oshin $^{\circledR}$, Nomolt ${ }^{\circledR}$ and Radiant $^{\circledR}$ ) (T11) was the most effective treatment on the spiny bollworm which decreased the inspected number of the spiny bollworm larvae up to 0.50 larva/ 75 bolls as compared with the untreated check which recorded the highest mean number of 17.33 larvae/ 75 bolls. 
Table (3): Effect of Trichogramma release and application of tested insecticides on seed cotton yield during the season of 2013

\begin{tabular}{cccccc}
\hline Treatment & $\begin{array}{c}\text { Weight of seed } \\
\text { cotton /40 } \\
\text { plant (g) }\end{array}$ & $\begin{array}{c}\text { Weight/plant } \\
\mathbf{( g )}\end{array}$ & $\begin{array}{c}\text { Weight/plant } \\
\mathbf{( k g )}\end{array}$ & $\begin{array}{c}\text { Weight/fed. } \\
\mathbf{( k g )}\end{array}$ & $\begin{array}{c}\text { Cotton } \\
\text { yield/fed } \\
\text { (Ken) }\end{array}$ \\
\hline T1 & 1257.60 & 31.44 & 0.0314 & 1414.80 & $8.98^{\mathrm{a}^{*}}$ \\
T2 & 1152.00 & 28.80 & 0.0288 & 1296.00 & $8.23^{\mathrm{b}}$ \\
T3 & 1040.00 & 26.00 & 0.0260 & 1170.00 & $7.43^{\mathrm{d}}$ \\
T4 & 910.40 & 22.67 & 0.0228 & 1026.00 & $6.50^{\mathrm{e}}$ \\
T5 & 704.00 & 17.60 & 0.0176 & 792.00 & $5.03^{\dagger}$ \\
T6 & 712.00 & 17.80 & 0.0178 & 801.00 & $5.08^{\dagger}$ \\
T7 & 1008.00 & 25.20 & 0.0252 & 1134.00 & $7.20^{\mathrm{d}}$ \\
T8 & 1116.00 & 27.90 & 0.0279 & 1255.50 & $7.97^{\mathrm{bc}}$ \\
T9 & 1060.00 & 26.50 & 0.0265 & 1192.50 & $7.57^{\mathrm{cd}}$ \\
\hline Control & 603.20 & 15.08 & 0.0151 & 678.60 & $4.31^{\mathrm{g}}$ \\
\hline
\end{tabular}

*Means followed with the same letter(s) (in a column) are not significantly different at 0.05 level of probability.

It is also noticed that all the performed treatments (15 treatments) were effective in controlling the spiny bollworm in the field, nevertheless, the treatment of releasing the parasitoid $T$. evanescens alone (T9) was not so effective as the other performed treatments, whereas the mean number of the spiny bollworm larvae was as high as 14.50 larvae/75 bolls was merely close to the highest recorded mean for the control treatment (17.33 larvae/ 75 bolls). The means numbers of larvae recorded for the rest of the other conducted treatments were less than 1.50 larvae/ 75 bolls and ranged between 0.62 and 1.41 larvae/75 bolls (T10 and T12, in respect).

In general, it could be concluded that the treatment of cotton fields with the parasitoid Trichogramma as individual release was not sufficient to suppress the bollworms infestation, whereas, satisfactory results were obtained when the parasitoid releases were integrated with certain tested pesticides. Hence, higher reduction in the spiny bollworm population and greater cotton yields were achieved with this integration. In this respect,

Salman et al. (2014) reported that the effect of the parasitoid T. evanescens treated alone against the spiny bollworm population was slight. On the other hand, El-Heneidy et al. (2004) showed that the release of Trichogramma evanescens achieved significant reductions in the percentages of bollworms' infestation comparing with those areas treated with different insecticides at the same working sites. Contrarily, Abd El-Hafez et al. (2005) reported the insignificant differences between the bollworms infestations in Trichogramma and/or insecticide-treatments during two seasons of growing cotton. 
Table (4): Effect of Trichogramma release and application of different insecticides on the loss of cotton bolls (\%) during the growing cotton season of 2013

\begin{tabular}{cccccccccc}
\hline TREATMENT & $\begin{array}{c}\text { Non- infested } \\
\text { open bolls } \\
\text { (A) }\end{array}$ & $\begin{array}{c}\mathbf{2 / 3} \text { open } \\
\text { bolls } \\
\text { (B) }\end{array}$ & $\begin{array}{c}\mathbf{1 / 3} \text { open } \\
\text { bolls } \\
\text { (C) }\end{array}$ & $\begin{array}{c}\text { Infested } \\
\text { dry bolls } \\
\text { (D) }\end{array}$ & $\begin{array}{c}\text { Infested } \\
\text { green bolls } \\
\text { (E) }\end{array}$ & $\begin{array}{c}\text { Theoretical } \\
\text { open bolls } \\
\text { (TH) } \\
\text { (F) }\end{array}$ & $\begin{array}{c}\text { Observed } \\
\text { open bolls } \\
\text { (G) }\end{array}$ & $\begin{array}{c}\text { (F-G) } \\
\text { (H) }\end{array}$ & $\begin{array}{c}\text { Loss\%** } \\
\text { (I) }\end{array}$ \\
\hline T1 & 420.00 & 42.00 & 9.00 & 14.00 & 18.00 & 503.00 & 451.00 & 52.00 & $10.30^{\mathrm{e}^{*}}$ \\
T2 & 402.00 & 46.00 & 20.00 & 21.00 & 19.00 & 508.00 & 439.00 & 69.00 & $13.50^{\text {cd }}$ \\
T3 & 389.00 & 31.00 & 22.00 & 26.00 & 16.00 & 484.00 & 416.80 & 67.20 & $13.80^{\text {cd }}$ \\
T4 & 351.00 & 32.00 & 17.00 & 28.00 & 19.00 & 447.00 & 377.70 & 69.30 & $15.50^{\mathrm{c}}$ \\
T5 & 249.00 & 10.00 & 16.00 & 28.00 & 21.00 & 324.00 & 260.90 & 63.10 & $19.50^{\mathrm{b}}$ \\
T6 & 313.00 & 18.00 & 6.00 & 16.00 & 10.00 & 363.00 & 326.90 & 36.10 & $10.00^{\mathrm{e}}$ \\
T7 & 278.00 & 11.00 & 19.00 & 15.00 & 9.00 & 332.00 & 291.60 & 40.40 & $12.20^{\mathrm{de}}$ \\
T8 & 247.00 & 23.00 & 3.00 & 25.00 & 9.00 & 307.00 & 263.20 & 43.80 & $14.30^{\text {cd }}$ \\
T9 & 222.00 & 19.00 & 5.00 & 22.00 & 10.00 & 278.00 & 236.00 & 42.00 & $15.00^{\mathrm{c}}$ \\
\hline Control & 89.00 & 11.00 & 7.00 & 48.00 & 39.00 & 194.00 & 98.60 & 95.40 & $49.20^{\mathrm{a}}$ \\
\hline
\end{tabular}

${ }^{*}$ Means followed with the same letter(s) (in a column) are not significantly different at 0.05 level of probability.

** \% of loss $(I)=H / F$ X100 where H=F-G; G=A+B $[2 / 3])+C[1 / 3] ; F=A+B+C+D+E(E I-N a g a r, 1998)$ 
Table (5): Effect of Trichogramma evanescens release and application of different insecticides on the mean numbers of spiny bollworm larvae/75 bolls during the season of 2014.

\begin{tabular}{|c|c|c|c|c|c|c|c|c|c|c|c|c|c|c|}
\hline \multirow[b]{3}{*}{ Treatments } & \multirow[b]{3}{*}{$\begin{array}{c}\text { M.N.B. } \\
\text { S\# }\end{array}$} & \multicolumn{12}{|c|}{ Mean No. of spiny bollworm larvae } & \multirow[b]{3}{*}{$\begin{array}{c}\text { General } \\
\text { Mean }\end{array}$} \\
\hline & & \multicolumn{3}{|c|}{$1^{\text {st }}$ Spray } & \multicolumn{3}{|c|}{$2^{\text {nd }}$ Spray } & \multicolumn{3}{|c|}{$3^{\text {rd }}$ Spray } & \multicolumn{3}{|c|}{$4^{\text {th }}$ Spray } & \\
\hline & & $\begin{array}{c}1^{5 t^{\star \star \star}} \\
(17 / 8)^{\star}\end{array}$ & $\begin{array}{c}2^{\text {nd }} \\
(23 / 8)\end{array}$ & $\begin{array}{c}\text { Mean } \\
\text { No. of } \\
\text { larvae/ } \\
75 \text { bolls }\end{array}$ & $\begin{array}{c}3^{\text {rd }} \\
(30 / 8)\end{array}$ & $\begin{array}{l}4^{\text {th }} \\
(7 / 9)\end{array}$ & $\begin{array}{c}\text { Mean } \\
\text { No. of } \\
\text { larvae/ } \\
75 \text { bolls }\end{array}$ & $\begin{array}{c}5^{\text {th }} \\
(15 / 9)\end{array}$ & $\begin{array}{c}6^{\text {th }} \\
(23 / 9)\end{array}$ & $\begin{array}{l}\text { Mean } \\
\text { No. of } \\
\text { larvae/ } \\
75 \text { bolls }\end{array}$ & $\begin{array}{c}7^{\text {th }} \\
(30 / 9)\end{array}$ & $\begin{array}{l}8^{\text {th }} \\
(7 / 10)\end{array}$ & $\begin{array}{c}\text { Mean } \\
\text { No. of } \\
\text { larvae/ } \\
75 \text { bolls }\end{array}$ & \\
\hline T1 & 2.33 & $1.00^{\mathrm{bc} c^{\star \star}}$ & $1.66^{c}$ & $1.33^{b}$ & $1.33^{\mathrm{C}}$ & $1.00^{c}$ & $1.16^{\mathrm{c}}$ & $0.33^{\mathrm{cd}}$ & $1.66^{\mathrm{cd}}$ & $1.00^{\text {cde }}$ & $0.66^{c}$ & $0.66^{b}$ & $0.66^{b}$ & $1.04^{c}$ \\
\hline T2 & 2.33 & $1.00^{\mathrm{bc}}$ & $0.33^{\mathrm{C}}$ & $0.66^{b}$ & $1.00^{\mathrm{C}}$ & $1.33^{\mathrm{C}}$ & $1.16 \mathrm{c}$ & $0.66^{\mathrm{cd}}$ & $1.33^{\mathrm{cd}}$ & $1.00^{\text {cde }}$ & $0.33^{\mathrm{C}}$ & $0.33^{b}$ & $0.33^{b}$ & $0.79^{\mathrm{C}}$ \\
\hline T3 & 2.67 & $0.33^{\mathrm{C}}$ & $1.66^{\mathrm{C}}$ & $0.10^{b}$ & $1.33^{\mathrm{C}}$ & $1.33^{\mathrm{C}}$ & $1.33 \mathrm{c}$ & $1.00^{\mathrm{cd}}$ & $1.66^{\mathrm{cd}}$ & $1.33^{\text {cde }}$ & $0.66^{c}$ & $0.66^{b}$ & $0.66^{b}$ & $1.08^{\mathrm{C}}$ \\
\hline T4 & 2.67 & $0.33^{c}$ & $1.00^{c}$ & $0.66^{b}$ & $1.00^{c}$ & $1.66^{c}$ & $1.33 c$ & $0.66^{\mathrm{cd}}$ & $1.66^{\mathrm{cd}}$ & $1.16^{\text {cde }}$ & $1.00^{c}$ & $0.00^{b}$ & $0.50^{b}$ & $0.91^{c}$ \\
\hline T5 & 2.33 & $0.66^{c}$ & $1.00^{C}$ & $0.83^{b}$ & $0.66^{c}$ & $1.33^{\mathrm{C}}$ & $1.00^{C}$ & $0.33^{\mathrm{cd}}$ & $2.00^{C}$ & $1.16^{\text {cde }}$ & $0.66^{\mathrm{C}}$ & $0.33^{b}$ & $0.50^{b}$ & $0.87^{\mathrm{C}}$ \\
\hline T6 & 3.00 & $0.33^{\mathrm{C}}$ & $0.66^{c}$ & $0.50^{b}$ & $0.66^{\mathrm{C}}$ & $1.33^{\mathrm{C}}$ & $1.00^{C}$ & $0.66^{\mathrm{cd}}$ & $0.66^{d}$ & $0.66^{\mathrm{e}}$ & $1.00^{C}$ & $0.00^{b}$ & $0.50^{b}$ & $0.66^{c}$ \\
\hline T7 & 2.33 & $0.33^{\mathrm{C}}$ & $0.33^{c}$ & $0.33^{b}$ & $0.66^{\mathrm{C}}$ & $1.66^{\mathrm{C}}$ & $1.16^{\mathrm{C}}$ & $0.66^{\mathrm{cd}}$ & $2.00^{C}$ & $1.33^{\text {cde }}$ & $0.66^{c}$ & $0.66^{b}$ & $0.66^{\mathrm{b}}$ & $0.87^{\mathrm{C}}$ \\
\hline T8 & 3.00 & $0.66^{c}$ & $0.33^{c}$ & $0.50^{\mathrm{b}}$ & $1.00^{C}$ & $2.00^{c}$ & $1.50^{\mathrm{C}}$ & $1.00^{\mathrm{cd}}$ & $1.66^{\mathrm{cd}}$ & $1.33^{\text {cde }}$ & $1.00^{c}$ & $0.66^{b}$ & $0.83^{b}$ & $1.04^{c}$ \\
\hline T9 & 10.33 & $12.00^{a}$ & $10.00^{b}$ & $11.00^{a}$ & $17.33^{b}$ & $12.66^{b}$ & $15.00^{b}$ & $23.33^{b}$ & $20.33^{b}$ & $21.83^{b}$ & $9^{.00 b}$ & $11.66^{a}$ & $10.33^{a}$ & $14.5^{\mathrm{b}}$ \\
\hline T10 & 2.60 & $1.00^{\mathrm{bc}}$ & $0.00^{c}$ & $0.50^{b}$ & $0.33^{c}$ & $1.33^{\mathrm{C}}$ & $0.83^{c}$ & $0.66^{\mathrm{cd}}$ & $1.00^{\mathrm{cd}}$ & $0.83^{\mathrm{de}}$ & $0.66^{\mathrm{C}}$ & $0.00^{\mathrm{b}}$ & $0.33^{\mathrm{b}}$ & $0.62^{\mathrm{de}}$ \\
\hline T11 & 2.30 & $0.33^{c}$ & $0.33^{\mathrm{C}}$ & $0.33^{b}$ & $0.66^{\mathrm{C}}$ & $1.33^{\mathrm{C}}$ & $1.00^{c}$ & $0.00^{d}$ & $1.00^{\mathrm{cd}}$ & $0.50^{\mathrm{e}}$ & $0.33^{c}$ & $0.00^{b}$ & $0.16^{\mathrm{b}}$ & $0.50^{\mathrm{e}}$ \\
\hline T12 & 3.33 & $1.66^{\mathrm{bc}}$ & $2.00^{c}$ & $1.83^{b}$ & $1.00^{c}$ & $1.33^{c}$ & $1.16^{c}$ & $1.33^{c}$ & $2.33^{c}$ & $1.83 c$ & $1.00^{c}$ & $0.66^{b}$ & $0.83^{b}$ & $1.41^{\mathrm{c}}$ \\
\hline T13 & 4.67 & $1.66^{\mathrm{bc}}$ & $2.00^{c}$ & $1.83^{b}$ & $1.00^{c}$ & $2.00^{c}$ & $1.50^{c}$ & $1.33^{c}$ & $1.66^{\mathrm{cd}}$ & $1.5^{\mathrm{cd}}$ & $0.66^{c}$ & $0.66^{b}$ & $0.66^{b}$ & $1.37^{\mathrm{C}}$ \\
\hline T14 & 4.33 & $2.33^{b c}$ & $1.66^{c}$ & $2.00^{b}$ & $1.33^{c}$ & $2.33^{c}$ & $1.83^{c}$ & $0.66^{\mathrm{cd}}$ & $1.00^{\mathrm{cd}}$ & $0.83^{\mathrm{de}}$ & $0.33^{c}$ & $0.00^{b}$ & $0.16^{b}$ & $1.21^{\mathrm{c}}$ \\
\hline T15 & 3.33 & $2.66^{b}$ & $1.66^{\mathrm{c}}$ & $2.16^{b}$ & $1.00^{c}$ & $1.33^{c}$ & $1.16^{\mathrm{c}}$ & $0.66^{\mathrm{cd}}$ & $1.00^{\mathrm{cd}}$ & $0.83^{\mathrm{de}}$ & $0.66^{c}$ & $0.00^{b}$ & $0.33^{b}$ & $1.12^{\mathrm{C}}$ \\
\hline Untreated Check & 12.67 & $11.66^{\mathrm{a}}$ & $12.66^{\mathrm{a}}$ & $12.16^{a}$ & $25.00^{a}$ & $1600^{\mathrm{a}}$ & $20.50^{a}$ & $24.66^{a}$ & $24.66^{a}$ & $24.66 a$ & $10.66^{\mathrm{a}}$ & $13.33^{a}$ & $12.00^{a}$ & $17.33^{\mathrm{a}}$ \\
\hline
\end{tabular}

\# Mean numbers of larvae before Spray

${ }^{*}$ Inspection date (day/Month)

${ }^{* *}$ Means followed with the same letter(s) (in a column) are not significantly different at 0.05 level of probability.

$\star * * 1^{\text {st }}$ inspection was done 7 days post- application and $2^{\text {nd }}$ one was done 14 days post-application. 
Data presented in Table (6) exhibit the effect of the different performed and suggested treatments combining the release of the parasitoid $T$. evanescens and the application of different insecticides on seed cotton yield. The treatment of $T$. evanescens $+\left(\mathrm{Pleo}^{\circledR}\right.$, Challenger $\left.^{\circledR}, \mathrm{Pleo}^{\circledR}\right)($ T4) recorded the highest seed cotton yield (9.43ken./fed) compared with the untreated check (4.14 ken./fed), followed by T10 (F. + T. evanescens + Oshin $^{\circledR}$, Nomolt ${ }^{\circledR}$, $\left.\mathrm{Pleo}^{\circledR}\right)(9.28 \mathrm{ken} . / \mathrm{fed})$ and both of T5 (T. evanescens $+\left(\mathrm{Oshin}^{\circledR}\right.$, Nomolt ${ }^{\circledR}$, $\left.\mathrm{Pleo}^{\circledR}\right)$ ) and T11 (F.+ T. evanescens+ $\left[\mathrm{Pleo}^{\circledR}\right.$, Challenger $^{\circledR}$, Pleo $\left.{ }^{\circledR}\right]$ ) which showed the same amount of yield that reached $9.14 \mathrm{ken} . / \mathrm{fed}$. Trichogramma evanescens alone (T9) gave the lowest seed cotton yield (4.31 ken./fed.) and this yield value was so close to that of the untreated check treatment $(4.14$ ken./fed.).

The percentages of cotton bolls loss were varied due to the application of different combined treatments (Table 7). Noticeably, as T4 and T10 recorded the higher yield values, they also recorded lower loss percentages of cotton bolls (6.50 and $7.50 \%)$. The recorded loss percentage of cotton bolls in control treatment was as high as nearly half of the all formed bolls of the grown plants (48.50\%). Meanwhile, the recorded percentage of loss for T9 ( $T$. evanescens alone) was as high as $33.71 \%$ and that loss value was higher than those of the other performed treatments. The percentage of loss in case of the release of the parasitoid $T$. evanescens alone was about two third $(2 / 3)$ of that of control treatment and this means that the release of the parasitoid alone was not so efficient for controlling the spiny bollworm E. insulana. Nevertheless, Abd EIRahman et al. (2008) found that five releases (17600 adult females in 2waves / feddan / release) in two weeks intervals successfully suppressed cotton bollworm infestation to be one fourth to one third of that of the untreated cotton fields.

In general, it could be concluded that the treatment of cotton fields with the parasitoid Trichogramma alone was not entirely sufficient to suppress the spiny bollworm infestation, whereas, satisfactory results can be obtained when the parasitoid releases are integrated with certain pesticides. Hence, higher reduction in the spiny bollworm population, greater cotton yield and less loss of cotton bolls can be achieved with this integration. 
Table (6): Effect of Trichogramma release and the application of different insecticides on cotton yield during the season of 2014

\begin{tabular}{|c|c|c|c|c|c|}
\hline Treatment & $\begin{array}{c}\text { Weight of } \\
\text { seed cotton/ } \\
\text { 40 plants } \mathbf{( g )}\end{array}$ & $\begin{array}{c}\text { Weight/plant } \\
\mathbf{( g )}\end{array}$ & $\begin{array}{c}\text { Weight/plant } \\
\text { (kg) }\end{array}$ & $\begin{array}{c}\text { Weight/fed. } \\
\text { (kg) }\end{array}$ & $\begin{array}{c}\text { Seed Cotton } \\
\text { yield/ ed. } \\
\text { (Ken) }\end{array}$ \\
\hline T1 & 1140.00 & 28.50 & 0.0285 & 1282.50 & $8.14^{\text {ef }}$ \\
\hline T2 & 1104.00 & 27.60 & 0.0276 & 1242.00 & $7.88^{\mathrm{f}}$ \\
\hline T3 & 1084.00 & 27.10 & 0.0271 & 1219.50 & $7.74^{\dagger}$ \\
\hline T4 & 1320.00 & 33.00 & 0.0330 & 1485.00 & $9.43^{\mathrm{a}}$ \\
\hline T5 & 1280.00 & 32.00 & 0.0320 & 1440.00 & $9.14^{\mathrm{ab}}$ \\
\hline T6 & 1264.00 & 31.60 & 0.0316 & 1422.00 & $9.03^{\mathrm{ab}}$ \\
\hline T7 & 1272.00 & 31.80 & 0.0318 & 1431.00 & $9.08^{\mathrm{ab}}$ \\
\hline T8 & 1284.00 & 32.10 & 0.0321 & 1444.50 & $9.17^{\mathrm{ab}}$ \\
\hline T9 & 604.00 & 15.10 & 0.0151 & 679.50 & $4.31^{\mathrm{g}}$ \\
\hline T10 & 1300.00 & 32.50 & 0.0325 & 1462.50 & $9.28^{\mathrm{ab}}$ \\
\hline T11 & 1280.00 & 32.00 & 0.0320 & 1440.00 & $9.14^{\mathrm{ab}}$ \\
\hline T12 & 1204.00 & 30.10 & 0.0301 & 1354.50 & $8.60^{\text {cd }}$ \\
\hline T13 & 1128.00 & 28.20 & 0.0282 & 1269.00 & $8.06^{\mathrm{ef}}$ \\
\hline T14 & 1112.00 & 27.80 & 0.0278 & 1251.00 & $7.94^{\mathrm{f}}$ \\
\hline T15 & 1160.00 & 29.00 & 0.0290 & 1305.00 & $8.28^{\mathrm{de}}$ \\
\hline Control & 580.00 & 14.50 & 0.0145 & 652.500 & $4.14^{\mathrm{g}}$ \\
\hline
\end{tabular}

${ }^{*}$ Means followed with the same letter(s) (in a column) are not significantly different at 0.05 level of probability. 
Table (7): Effect of Trichogramma release and the application of different insecticides on the loss of cotton bolls (\%) during the cotton growing season of 2014.

\begin{tabular}{|c|c|c|c|c|c|c|c|c|c|}
\hline TREATMENT & $\begin{array}{c}\text { Non- } \\
\text { infested } \\
\text { open bolls } \\
\text { (A) }\end{array}$ & $\begin{array}{l}2 / 3 \text { open } \\
\text { bolls } \\
\text { (B) }\end{array}$ & $\begin{array}{l}\text { 1/3 open } \\
\text { bolls } \\
\text { (C) }\end{array}$ & $\begin{array}{l}\text { Infested } \\
\text { dry bolls } \\
\text { (D) }\end{array}$ & $\begin{array}{c}\text { Infested } \\
\text { green bolls } \\
\text { (E) }\end{array}$ & $\begin{array}{l}\text { Theoretical } \\
\text { open bolls } \\
\text { (TH)(F) }\end{array}$ & $\begin{array}{l}\text { Observed } \\
\text { open bolls } \\
(\mathrm{O})(\mathrm{G})\end{array}$ & $\begin{array}{c}\text { Th-O } \\
\text { (F-G) } \\
(\mathrm{H})\end{array}$ & $\begin{array}{c}\text { Loss \% } \\
\text { (I) }\end{array}$ \\
\hline T1 & 431.00 & 37.67 & 17.00 & 29.00 & 4.00 & 518.67 & 460.76 & 57.91 & $11.17^{\text {cdet }^{*}}$ \\
\hline T2 & 394.67 & 40.67 & 23.33 & 20.33 & 7.33 & 486.33 & 425.80 & 60.40 & $12.50^{\text {cde }}$ \\
\hline T3 & 476.67 & 52.67 & 29.67 & 23.33 & 6.00 & 588.33 & 516.28 & 68.72 & $12.04^{\text {cdet }}$ \\
\hline T4 & 694.33 & 43.33 & 21.00 & 20.33 & 2.33 & 781.33 & 729.98 & 51.35 & $6.50^{\mathrm{g}}$ \\
\hline T5 & 618.67 & 40.67 & 30.67 & 25.00 & 2.67 & 721.00 & 655.87 & 65.12 & $9.00^{\operatorname{detg}}$ \\
\hline T6 & 388.00 & 33.00 & 15.67 & 25.33 & 5.00 & 467.00 & 415.10 & 51.90 & $11.00^{\text {cdetg }}$ \\
\hline T7 & 483.00 & 39.33 & 25.00 & 17.00 & 3.00 & 567.33 & 517.57 & 49.77 & $9.30^{\text {cdetg }}$ \\
\hline T8 & 479.33 & 38.33 & 38.33 & 22.33 & 5.00 & 565.67 & 511.53 & 54.13 & $9.57^{\text {cdetg }}$ \\
\hline T9 & 101.00 & 26.00 & 13.33 & 23.00 & 19.00 & 185.67 & 122.42 & 63.11 & $33.71^{b}$ \\
\hline T10 & 410.67 & 35.00 & 17.33 & 9.67 & 2.33 & 475.00 & 439.49 & 35.51 & $7.50^{\dagger g}$ \\
\hline T11 & 505.33 & 52.33 & 31.33 & 6.67 & 3.33 & 599.00 & 550.21 & 48.79 & $8.00^{\text {etg }}$ \\
\hline T12 & 363.67 & 45.00 & 35.33 & 13.00 & 5.67 & 462.33 & 401.82 & 60.52 & $13.00^{\mathrm{cd}}$ \\
\hline T13 & 446.33 & 58.67 & 35.00 & 23.33 & 11.00 & 574.33 & 496.58 & 77.75 & $13.50^{\mathrm{cd}}$ \\
\hline T14 & 437.67 & 55.00 & 36.33 & 26.67 & 8.67 & 564.33 & 485.96 & 78.38 & $14.03^{c}$ \\
\hline T15 & 435.33 & 36.00 & 30.67 & 23.00 & 8.33 & 539.33 & 473.18 & 66.15 & $12.03^{\text {cdet }}$ \\
\hline Control & 78.33 & 25.33 & 18.00 & 36.67 & 37.33 & 195.67 & 100.99 & 94.68 & $48.50^{a}$ \\
\hline
\end{tabular}

*Means followed with the same letter(s) (in a column) are not significantly different at 0.05 level of probability. 


\section{REFERENCES}

Abd El-Hafez, Alia M., W. M. Watson, M. A. Essa and Kh. G. H. El-Malki (2005). Control of Pectinophora gossypiella (Saund.) and Earias insulana (Boisd.) in cotton fields by releasing Trichogramma evanescens Westwood. Beltwide Cotton Conf., New Orleans, Louisiana, 4 -7, Jan., 610.

Abd El-Rahman, A.G., Alia M. AbdEl-Hafez, Bahira, M. El-Sawaf, M.R. Baraka and A.I. Imam (2008). Efficacy of the egg parasitoid, Trichogramma evanescens West. in suppressing spiny bollworm, Earias insulana (Boisd.) infestation in El- Farafra cotton fields, New valley Governorate, Egypt. Egypt. J. Biol. Pest Control, 18 (2): 265- 269.

Al-Ameer, M. A., M. E. Abd El-Salam, W. M. B. Yehia and I. A. I. Saad (2010) . Evaluation of some cotton genotypes for ability to infestation tolerance to bollworms for improving of some important economic characters. J. Agric. Res. Kafer El-Shiekh Univ., 36 (2):147-162.

Amin, A. A. and M. F. Gergis (2006). Integrated management strategies for control of cotton key pests in middle Egypt. Agron. Res., 4:121-128.

Aziz, M. A. (2011). Arab Republic of Egypt, statement of the Egyptian delegation. The 69th Plenary Meeting International Cotton Advisory committee - September Lubbock, Texas, USA, pp: 18.

Bhatti, J. A., M. A. Khan, M. A. Murtaza, M. Z. Majeed and F. F. Jamil (2007). Response of American bollworm (Helicoverpa armigera HUB.) to weather factors in cotton under unsprayed conditions. J. Agric. Res., 45(3):209214.

Duncan, D.B.(1955) . Multiple range and multiple $F$ test. Biometrics, 11:1-42.

El-Bassiuony, H. M. (2012). Accumulative effect of chemical and biological control measures for cotton pests in reducing cotton bollworms infestation..Ph.D Thesis, Faculty of Agric. (Saba-Basha), Alexandria University, Egypt.

El-Basyouni, S. A. (2003). Efficiency of some conventional insecticides on controlling the larvae of the bollworms Pectinophora gossypiella and Earias insulana. J. Agric. Sci. Mansoura Univ., 28(3): 1901-1906.

Elgohary, Laila R. (2014). Field evaluation of some insecticides against the pink bollworm, Pectinophora gossypiella and the spiny bollworm, Earia sinsulana. J. Agric. Veter. Sci. Qassim Univ., 7(1): 35-42.

El-Heneidy, A. H., A. A. Khidr, A. M. Matar, A. Abdel-Halim and M. S. Hegab (2004 ). Proper timing and number of releases of the egg parasitoid, Trichogramma evanescens for controlling the cotton bollworms in Egyptian cotton fields. Egypt. J. Biol. Pest Control, 14(1):15-19.

El-Nagar, A. Z. (1998). Evaluation of certain foliars and micro-elements in an integrated pest management (IPM) program to control cotton bollworms. M.Sc. Thesis, Fac. Agric. (Saba Basha). Alex Univ., Egypt.

Gergis, M. F., A. A. Hamid and S. A. Mostafa (2001). Biologically based new approach for management of cotton key pests in middle Egypt. Beltwide Cotton Conf., 2: 876-882.

Hosny, M. M., M. A. A. Assem and S. A. A. Nasr (1967). Entomological and Zoological Agriculture Pests. pp. 563-565. $1^{\text {st }}$ edition, Dar- El Maaref, Egypt.

Hussein, N.M., F. F. Shalaby, E. F. EL-Khayat, S. M. Tawfik and M. S. Salem (2002). Effect of certain agrochemicals on cotton a growth and 
bollworms infestation during three successive seasons at Kalubia Governorate, Egypt. 2nd Int. Conf., Plant Protection Res. Institute, Cairo, Egypt, 21-24December, pp 854-865.

Johnstone, D. R. (2006). Pest control for cotton production. Present practice and trends for the future. Pest. Sci., 9: 483-492.

Li, L.Y. (1994).Worldwide use of Trichogramma for biological control on different crops: a survey. In: Biological control with egg parasitoids. E. Wajnberg and S. A. Hassan (eds.). CAB International, Oxon, UK, pp 3753.

Mirmoayedi, A. and M. Maniee (2009) . Integrated pest management of cotton's spiny bollworm (Earias insulana) with spray of diazinon and release of green lacewings. J. Entomol., 6:56-61.

Mirmoayedi, A., M. Maniee and A. Yaghutipoor (2010). Control of cotton spiny bollworm, Earias insulana Boisduval, using three bio-insecticides, $B t$, spinosad and neem-azal. J. Entomol., 7 (3): 89-94.

Reed, W. (1977) Earias insulana (Boisd.). In: Diseases, pests and weeds in tropical crops.Kranz, J., H. Schmutterer and W. Koch (Editors).Verlag Paul Parey. Berlin and Hamburg. pp.666.

Saad A. S. A., E. H. Tayeb, H. A. Awad and Abeer S. A. Abdel Rehiem (2015). Trichogramma evanescens release in correlation with certain pesticides against the spiny bollworm, Earias insulana (Boisd.) (Lep., Noctuidae) infestation in early and late cotton cultivation. Middle East $\mathrm{J}$. Appl. Sci., 5 (2): 290-296.

Saini, R. K. and R. Singh (2002). Host plant preference for oviposition by the spiny bollworm, Earias insulana Boisd. (Lepidoptera: Noctuidae). J. Appli. Entomo., 123 (4): 241-246.

Salman, A. M. A., G. A. Karaman, A. A. El-Zoghbey and A. R. A. Mazeed (2014). Biological control of certain insect pests attacking cotton plants in Sohag Governorate. Middle East J. Agric. Res., 3(2 ): 201-207.

USDA Foreign Agricultural Service (2015). Gain Report, Global Agriculture Information Network. Egypt Cotton and Products Annual Cash Subsidies Removed, Farmers to Contract their Crop before Cultivation.pp.12.

Younis, A. M., H. H. S. Hamouda, A. S. Ibrahim and M. A. Z. Zeitoun (2007). Field evaluation of certain pesticides against the cotton bollworms with special reference to their negative impact on beneficial arthropod. African Crop Sci. Conf. Proceed. 8th African Crop Sci. Soc., Elminia, Egypt, October 27-31, pp. 993-1002. 


\section{الملخص العريسي}

\section{الأساليب البيولوجية والكيميائية للمكافحة المتكاملة لدودة اللوز الشوكية}

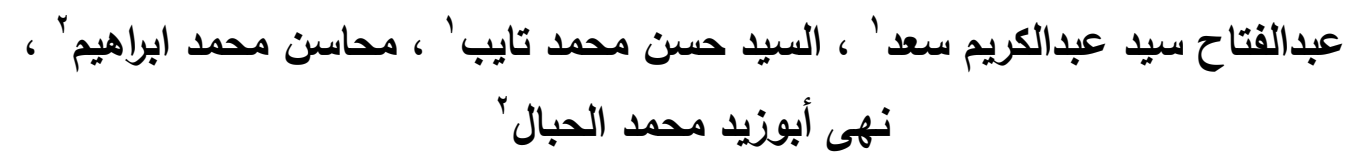

ا قسم وقاية النبات - كلية الزراعة (سابا باشا) - جامعة الإسكندرية

r معهد وقاية النباتات- محطة البحوث الزراعية - الصبحية - الإسكندرية

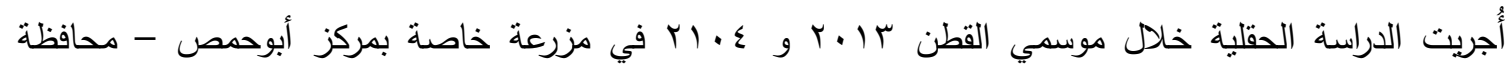

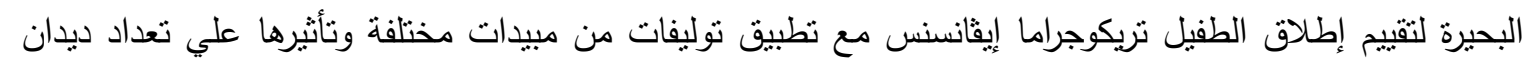

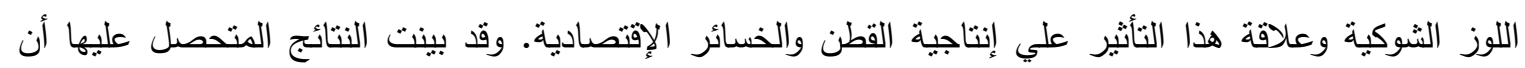

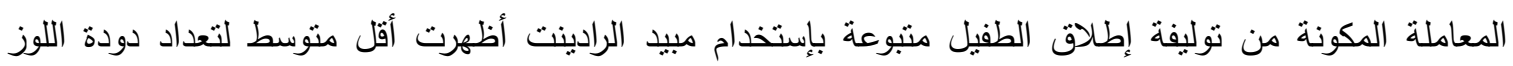

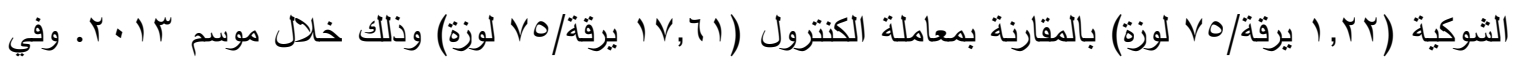

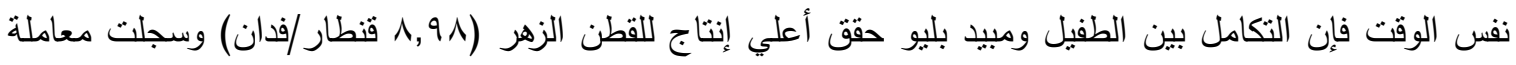

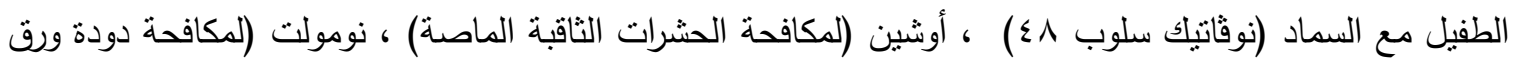
القطن) وبستبان أقل خفض في لوز القطن ( . ., • ( \%).

أما في خلال موسم ع ا.ب فقد أظهرت نوليفة المعاملة المكونة من إطلاق الطفيل ومبيدات أوشين

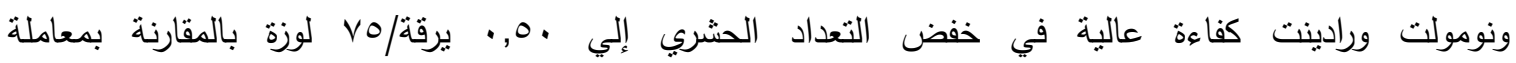

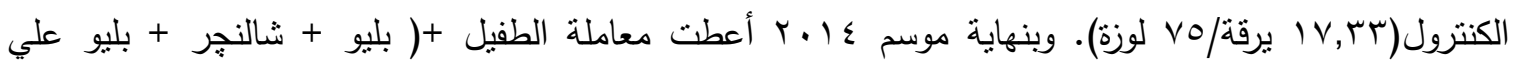

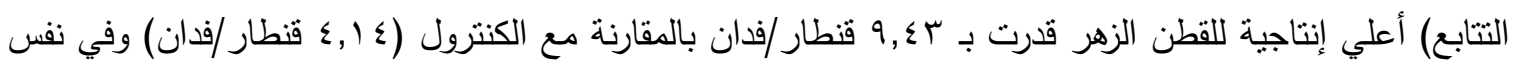

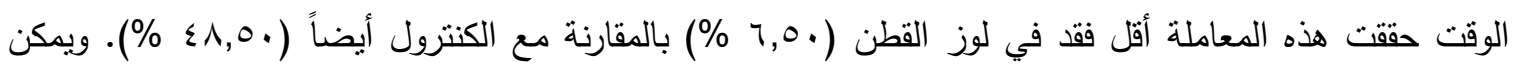
إجمال القول بأن كل المعاملات المقترحة والمنفذة بإطلاق الطفيل مع تطبيق توليفات من المبيدات سجلت أعلي انتاج عما سجلته معاملة الكنترول. 